\title{
Pengembangan Desa Wisata Melalui Sosialisasi Pembentukan Kelompok Sadar Pariwisata (POKDARWIS)
}

\author{
Abdurrahman ${ }^{1 *}$, Putri Ayu Hidayatur Rafiqah ${ }^{2}$, Khairussalam3, Said Khaidir $^{4}$, Bhentar Syamboga $^{5}$, \\ Aulia Fajar Nurrahman ${ }^{6}$, Dinar Adis Tiyani $^{7}$, Erna Rusyida Sa'adiyah ${ }^{8}$, Novita Yuliana9, Elisa Ivo \\ Pratiwi $^{10}$ \\ 1,2,3Universitas Lambung Mangkurat, Fakultas Ilmu Sosial dan Ilmu Politik, Jl. H. Hassan Basry, Banjarmasin, \\ Indonesia, \\ 4,5,6,7,8,9,10 Mahasiswa Program Studi Ilmu Pemerintahan, Universitas Lambung Mangkurat, Fakultas Ilmu Sosial \\ dan Ilmu Politik, Jl. H. Hassan Basry, Banjarmasin, Indonesia, \\ Email Korespondensi: Abdurrahman.fisip@ulm.ac.id
}

Diajukan

29 Oktober 2021

\section{Keywords:}

Desa Wisata

Kelompok Sadar Pariwisata

Pengabdian Desa

Desa Paring Tali

\section{Informasi Artikel}

Diterima

20 November 2021
Diterbitkan

30 November 2021

\begin{abstract}
Paring Tali Village is one of the villages in Simpang Empat District, Banjar Regency, South Kalimantan Province. Paring Tali village has tourism potential that can be developed as a tourist village. Paring Tali (Parta) Lake is one of the tourism potentials with an area of 5 ha. The development of Lake Parta tourism has been carried out since 2015 but is not managed sustainably due to a land dispute between the village government and the private sector. Therefore, through the socialization of tourism village development, it is expected to empower village communities in tourism management. The purpose of Community Service is to broaden the horizons of village officials, empower communities related to the development of tourist villages, and increase public awareness of the importance of managing tourist villages. The method used is a descriptive analysis method with a qualitative approach. The implementation of the empowerment program is carried out through three stages, namely survey, socialization, and branding. This community service increases public awareness of the importance of tourism villages, and the Paring Tali Village is willing to form a tourism awareness group (POKDARWIS).
\end{abstract}

\section{ABSTRAK}

Desa Paring Tali merupakan salah satu Desa di Kecamatan Simpang Empat Kabupaten Banjar Provinsi Kalimantan Selatan. Desa Paring Tali memiliki potensi wisata yang dapat dikembangkan sebagai desa wisata. Danau Paring Tali (Parta) merupakan salah satu potensi wisata dengan luas 5 ha. Pengembangan pariwisata danau Parta telah dilakukan sejak tahun 2015 akan tetapi tidak dikelola secara berkelanjutan karena adanya sengketa lahan antara pemerintah desa dengan sektor swasta. Oleh karena itu melalui sosialisasi pengembangan desa wisata diharapkan mampu memberdayakan maysrakat desa dalam pengeloaan pariwisata. Tujuan dari Pengabdian Kepada Masyarakat (PKM) adalah untuk memperluas wawasan aparatur desa, pemberdayaan masyarakat terkait pengembangan desa wisata, serta meningkatkan kesadaran masyarakat akan pentingnya pengelolaan desa wisata. Metode dalam pengabdian masyarakat ini adalah metode analisis deskriptif dengan pendekatan kualitatif. Pelaksanaan program pemberdayaaan dilaksankan melalui dua tahapan yaitu sosialisai, dan branding. Hasil dari pengabdian kepada masyarakat ini adalah meningkatnya kesadaran masyarakat akan pentingnya desa wisata, dan pihak Desa Paring Tali berkeinginan untuk membentuk kelompok sadar wisata (POKDARWIS).

\section{Copyright and License:}

Authors retain copyright and grant the journal right of first publication with the work simultaneously licensed under a Creative Commons Attribution 4.0 International License that allows others to share the work with an acknowledgment of the work's authorship and initial publication in this journal. 


\section{PENDAHULUAN}

Bentuk pariwisata di Indonesia adalah model perkembangan pariwisata berbasis desa wisata. Melalui industri kreatif semakin maju karena dapat diaplikasikan dalam berbagai sektor salah satunya adalah pariwisata. Pengembangan wisata merupakan salah satu fokus pemerintah pusat sebagai upaya perbaikan pertumbuhan ekonomi. Perkembangan sektor pariwisata memiliki hubungan dengan perekonomian yang bertujuan sebagai peningkatan kesejahteraan masyarakat lokal yang tinggal disekitar lokasi wisata. Industri kreatif melalui pariwisata memiliki bentuk yang berbeda dengan unsur khas kebudyaan dan tradisi desa yang memiliki lokasi wisata tersebut.

Proses pengembangan desa wisata diperlukan peran kelembagaan sebagai wadah dalam menghimpun aspirasi dan penunjang keberhasilan sektor wisata. Urgensi kelembagaan dalam sektor wisata adalah sebagai wadah sekaligus penggerak dalam memfasilitasi aspirasi dan partisipasi masyarakat. Tahapan awal kelembagaan desa wisata dapat berbentuk kelompok sadar wisata (POKDARWIS) dalam peningkatan program desa wisata yang dijalankan oleh masyarakat. Selain POKDARWIS sebagai lembaga tahap awal terdapat pula lembaga sistem sebagai pendukung yakni Dinas Pariwisata Provinsi dan Kabupten serta kebijakan pemerintah desa yang berhubungan dengan pengelolaan dan pengembangan desa wisata.

Secara umum Pemerintah daerah memiliki aturan sebagai acuan dalam penyelenggraan kepariwisataan. Secara khusus pemerintah daerah Kabupaten Banjar melalui peraturan daerah nomor 1 tahun 2013 tentang penyelenggaraan Kepariwisataan (Lembaran daerah Kabupaten Banjar Tahun 2013 Nomo 1, Tambahan Lembaran Daerah Kabupaten Banjar Nomor 1. penyelenggraan kepariwisatan bertujuan untuk menumbuhkan sikap saling pengertian dan saling percaya antar sesama manusia, memupuk rasa cinta, kebanggaan terhadap daerah serta memberikan kesempatan peran serta epada masyarakat. Desa wisata merupakan upaya pemerintah dalam memberikan pemberdayaan kepada masyarakat desa sebagai wujud pengembangan kapasitas sumber daya manusia. Pemberdayaan masyarakat adalah upaya dalam meningkatkan harkat dan martabat lapisan masyarakat yang dalam kondisi sekarang tidak mampu melepaskan diri dari perangkap kemiskinan dan keterbelakangan (Kartassmita, 1997: 11 dalam Andriyani, 20170. Melalui pemberdayaan masyarakat dalam bentuk sosialisasi diharapkan mampu memperluas wawasan bagi masyarakat akan pentingnya pengelolaan potensi desa (wisata) yang berlokasi di desa tersebut.

Desa Paring Tali merupakan salah satu desa di Kecamatan Simpang Empat Kabupaten Banjar Provinsi Kalimantan Selatan. Desa Paring Tali memiliki potensi wisata yang dapat dikembangkan sebagai desa wisata. Danau Paring Tali (Parta) merupakan salah satu potensi wisata berupa danau biru dengan luas 5 ha. Pengembangan danau Parta telah dilakukan sejak tahun 2015 akan tetapi tidak dikelola secara berkelanjutan. Potensi daerah tersebut terbengkalai karena sengketa lahan antara pemerintah desa dengan sektor swasta. hal tersebut menjadi salah satu penghambat dalam pengelolaan pengembangan desa wisata

Berdasarkan fenomena yang telah diuraikan di atas maka pengabdian kepada masyarakat berfokus kepada sosialisasi pengembangan desa wisata melalui pembentukan kelompok sadar pariwisata (POKDARWIS) yang bertujuan memperluas wawasan aparatur desa sebagai langkah konkrit untuk pengembangan desa wisata melalui pemerdayaan masyarakat. Selain itu peran serta kelembagaan diperlukan sebagai pelaku dan kontrol pelaksaanaan startegi pengembngan desa

\section{METODE}

Metode yang digunakan dalam Pengabdian Kepada Masyarakat (PKM) ini menggunakan metode analisis deskriptif dengan pendekatan kualitatif. Menurut I Made Wirartha (2006:155) metode analisis deskriptif kualitatif adalah menganalisis, menggambarkan, dan meringkas berbagai kondisi, situasi dari berbagai data yang dikumpulkan berupa hasil wawancara atau pengamatan mengenai masalah yang di teliti yang terjadi dilapangan. Pelaksanaan program pemberdayaan masyarakat dilakukan di Desa Paring Tali, Kecamatan Simpang Empat, Kabupaten Banjar melalui Sosialisasi.

Tahapan pelaksanaan program untuk pengembangan desa wisata yaitu sosialisasi berupa pentingnya kelembagaan melalui pembentukan kelompok sadar wisata (POKDARWIS dalam pengelolaan desa wisata. Dalam sosialisasi peserta juga diberikan buku Panduan Pembentukan Kelompok Sadar Pariwisata dan buku Pedoman Desa Wisata. Pelaksanaan selanjutnya menggunakan metode Branding (pemasaran). Branding adalah aktivitas berkomunikasi yang brtujuan untuk mendapatkan respon dari 
stakeholders atau konsumen (Prasetyo, 2020:6). Pemasaran dilakukan dengan berbagai cara, antara lain yaitu: pemasangan banner Pariwisata danau biru paring tali dan pemanfaatan media massa wisata.

\section{HASIL DAN PEMBAHASAN}

Pengembangan Desa Wisata Melalui Sosialisasi Pembentukan Kelompok Sadar Pariwisata (POKDARWIS) di Desa Paring Tali, Kecamatan Simpang Empat, Kabupaten Banjar dilaksanakan secara bertahap melalui beberapa proses yang melibatkan seluruh aspek masyarkat, pemerintah desa, dan pemerintah kabupaten. Adpun Tahapan yang dilakukan pada kegiatan sosialisasi pengembangan desa wisata sebagai berikut:

\section{Tahapan Persiapan}

Pengembangan Desa Wisata dalam buku Panduan Desa Wisata 2021 oleh Kementrian Pariwisata dan Ekonomi Kreatif dijabarkan dalam 4 (empat) kategori, yaitu Rintisan, Berkembang, Maju, dan Mandiri. Penentuan Klasifikasi Desa Wisata (atau sebutan lainnya) dapat dilakukan selamabat-lambatnya 2 (dua) tahun oleh Perangkat Desa yang membidangi pariwisata bersama dengan Organisasi Perangkat Daerah (OPD) yang membidangi pemberdayaan pemerintahan dan pemberdayaan masyarakat Desa (2021:42). klasifikasi desa wista sedikitnya memiliki potensi wisata di lokasi yang bersangkutan yang dapat dijadikan destinasi wisata serta memiliki sarana dan prasarana sebagai penunjang dalam pengembangan desa wisata.

Lokasi pengembangan desa wisata dalam pengabdian kepada masyarakat terletak di Desa Paring Tali Kecamatan Simpang Empat Kabupaten Banjar. Wisata Desa Paring Tali dahulunya pernah berkembang dan dikunjungi pariwisata, akan tetapi wisata kembali ditutup di akibatkan perselihisan lahan yang setengahnya dikelola oleh sektor swasta. Tahapan persiapan dilakukan koordinasi dan komunikasi dengan Aparatur Desa , Badan Permusyawaratan Desa,Pihak Swasta, dan RT Desa Paring Tali untuk memberikan penjelasan pengembangan Desa Wisata yang akan kembali dirintis oleh Desa Paring Tali. Persiapan selanjutnya melakukan koordinasi dan konsultasi kepada Dinas Budaya dan Pariwisata Kabupaten Banjar mengenai pengembangan Desa Wisata melalui pembentukan Kelompok Sadar Pariwisata (POKDARWIS) agar dalam merintis Desa Wisata di Desa Paring Tali melibatkan seluruh aspek pemberdayaan masyarakat melalaui POKDARWIS.

Tahapan persiapan berikutnya dilakukan peninjauan dan survei dalam penentuan pengembangan Desa Wisata. Klasifikasi Pengembangan Desa Wisata rintisan dalam Panduan Desa Wisata dengan menggunakan kriteria sebagai berikut (2021:46):

a. Masih berupa potensi yang dapat dikembangkan untuk menjadi destinasi wisata.

b. Pengembangan sarana prasana wisata masih terbatas.

c. Belum ada/masih sedikit sekali wisatawan berkunjung dan berasal dari masyarakat sekitar.

d. Kesadaran masyarakat terhadap potensi wisata belum tumbuh.

e. Sangat diperlukan pendampingan dari pihak terkait (pemerintah, swasta).

f. Memanfaatkan Dana Desa untuk pengembangan Desa Wisata.

g. Pengelolaan desa wisata masih bersifat lokal desa.

Setelah melaksanaan komunikasi dari berbagai aspek sebelum pelaksanaan sosialisasi dilakukan peninjauan sarana dan prasana untuk membangun Desa Wisata pada tahap rintisan. Peninjauan yang dilakukan seperti, akses jalan menuju desa (Gambar 1.) dan lahan wisata yang ingin dikembangkan oleh Desa Paring Tali (Gambar 2)

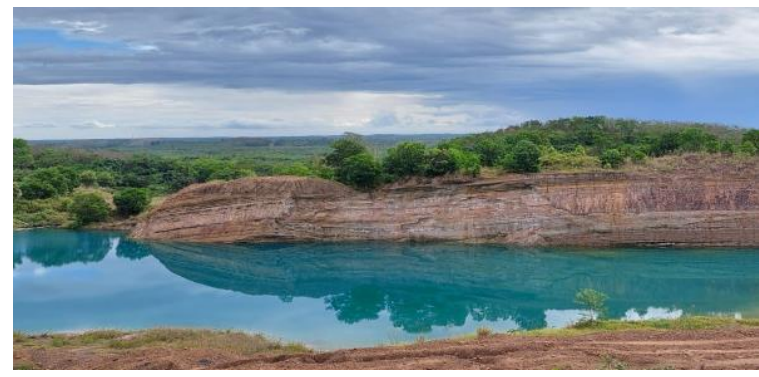

Gambar 1. Wisata Danau Biru Paring Tali yang akan dikembangkan oleh Desa Paring Tali

Journal Empowerment and Community Service Vol. 1, No. 01, November 2021 


\section{Tahapan Pelaksanaan Sosialisasi}

Melihat hasil dari peninjauan akses sarana dan prasarana serta wisata yang ingin dikembangkan oleh Desa Paring Tali diperlukan edukasi untuk meningkatkan peran masyarakat dalam pembangunan Desa Wisata yang memerlukan berbagai upaya pemberdayaan (empowerment), agar masyarakat dapat berperan lebih aktif dan optimal serta sekaligus menerima manfaat positif dari kegiatan pembangunan yang mensejahterakan masyarakat melalui Desa Wisata. Pelaksanaan Sosialisasi dilakukan secara bertahap melalui pemberian edukasi kepada aparatur desa, BPD, serta RT desa paring tali melalui pemberian buku Pedoman Desa Wisata (gambar 3.) dan Panduan Pembentukan Kelompok Sadar Pariwisata (gambar 4.)

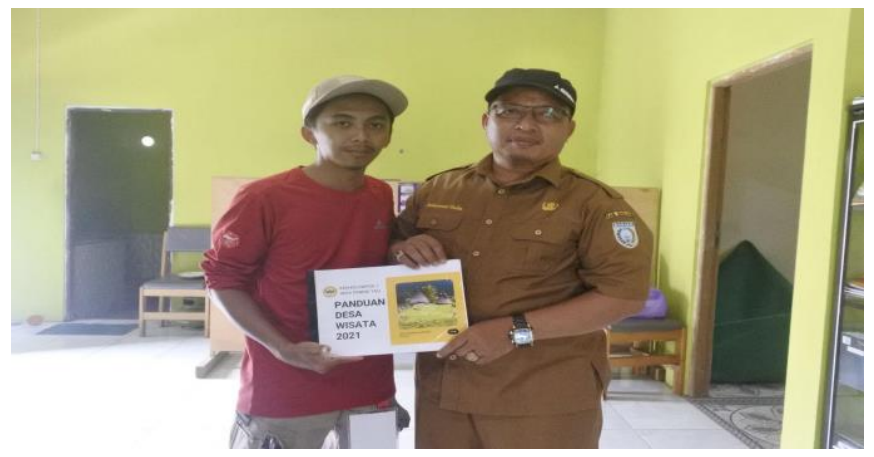

Gambar 2. Pemberian Buku Pedoman Desa Wisata

Tahap selanjutnya setelah memberikan sosialisasi kepada aparatur desa dan RT Desa Paring Tali, sosialisasi berikutnya melibatkan seluruh aspek masyarakat melalui komunikasi tiga arah melalui mahasiswa, aparatur Desa, dan Masyarakat (gambar 5.). Sosialisasi pembentukan Pokdarwis dengan memberdayaan masyarakat selaras dengan maksud dan tujuan pembentukan Pokdarwis yaitu (2012:17),

1. Maksud : Mengembangan Pokdarwis yang berperan sebagai motivator, penggerak, serta komunikator dalam upaya meningkatkan kesiapan dan kepedulian masyarakat disetikar destinasi pariwisata agar dapat berperan sebagai tuan rumah baik berkembangnya kepariwisataan, serta memiliki kesadaraan akan peluang dan nilai manfaat yang dapat dikembangkan dari kegiatan pariwisata untuk meningkatkan kesejahteraan ekonomi masyarakat.

2. Tujuan : Meningkatkan posisi dan peran masyarakat, membangun dan menumbuhkan sikap dan dukungan positif masyarakat sebagai tuan rumah, serta memperkenalkan, melestarikan, dan memanfaatkan potensi daya tarik wisata yang ada di masing-masing daerah.

Sosialisasi Pengembangan Desa Wisata melalui pembentukan Pokdarwis, dijelaskan secara subjektif melalui pedoman pengembangan desa wisata secara rintisan, maksud dan tujuan pembentukan Pokdarwis, fungsi dan kedudukan Pokdarwis, Keanggotaan, serta struktur kepengurusan Pokdarwis (gambar 6). Pembentukan Pokdarwis selanjutkan akan dibentuk oleh Aparatur Desa setelah dilaksanakannya sosialisasi mengikuti Pedoman Pembentukan Pokdarwis secara bertahap mengikuti skema pembentukan pokdarwis (gambar 7.) 
Gambar 6. Struktur Keorganisasian Pokdarwis

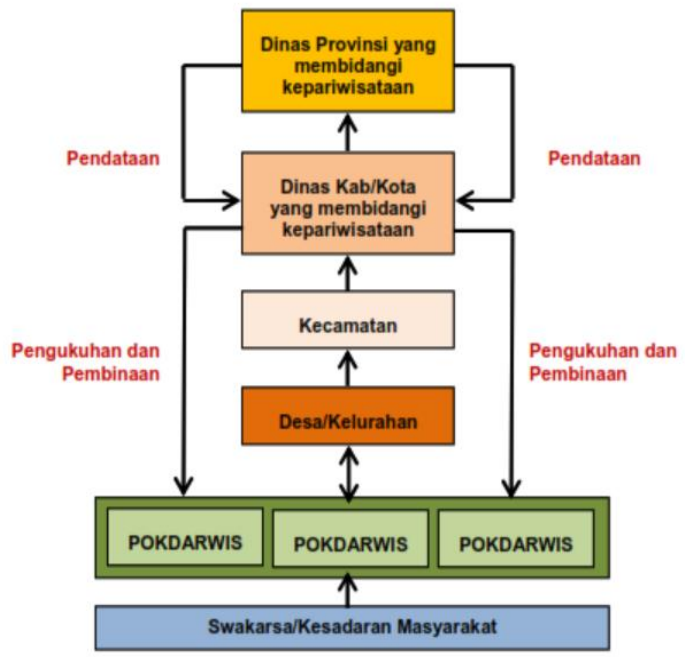

Gambar 3. Skema Pembentukan Pokdarwis

Sosialisasi memberikan motivasi kepada masyarakat untuk mengembangkan Desa Wisata melalui wisata Danau Biru Paring Tali yang dulu sempat ramai di datangi oleh wisatawan. Pengembangan Desa Wisata selanjutkan dilakukan oleh Aparatur Desa Paring tali dalam pemberdayaan masyarakat dan pengembangan wisata Danau Biru Paring Tali secara bertahap.

Setelah Pelaksanaan sosialisasi dilakukan branding secara bertahap melalui pemasangan banner ke danau biru (gambar 8) yang menumbuhkan motivasi masyarakat untuk mempromosikan desa wisata (gambar 9). Branding Danau Biru Paring Tali juga dipromosikan oleh media sosial wisata yang menjadikan Danau Biru Paring Tali dikenal wisatawan (gambar 10.)

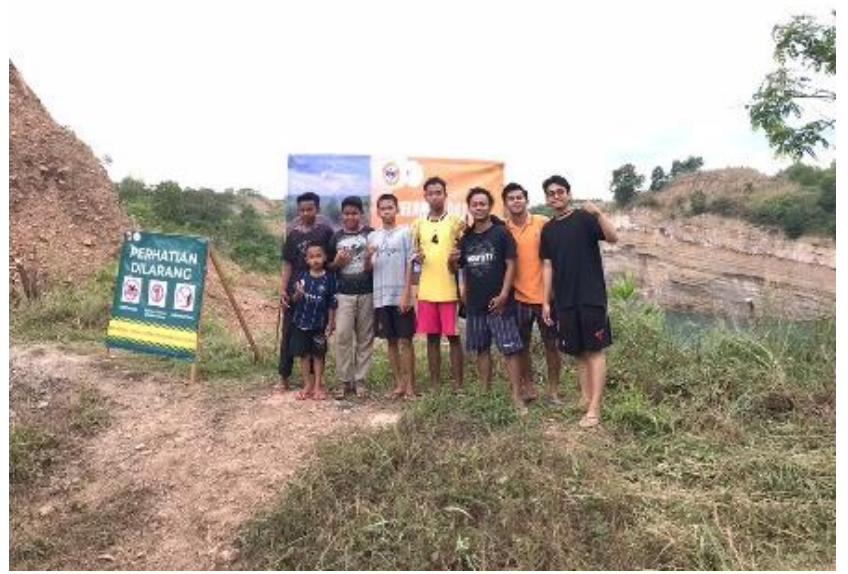

Gambar 4. Branding Wisata Danau Biru Paring Tali Melalui Pemasanagan Banner Wisata 


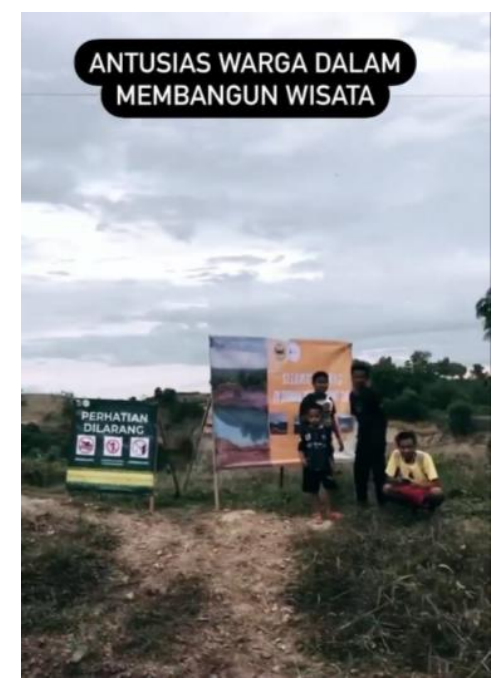

Gambar 5. Antusias Pemuda Desa Paring Tali dalam Branding Wisata Danau Biru Paring Tali
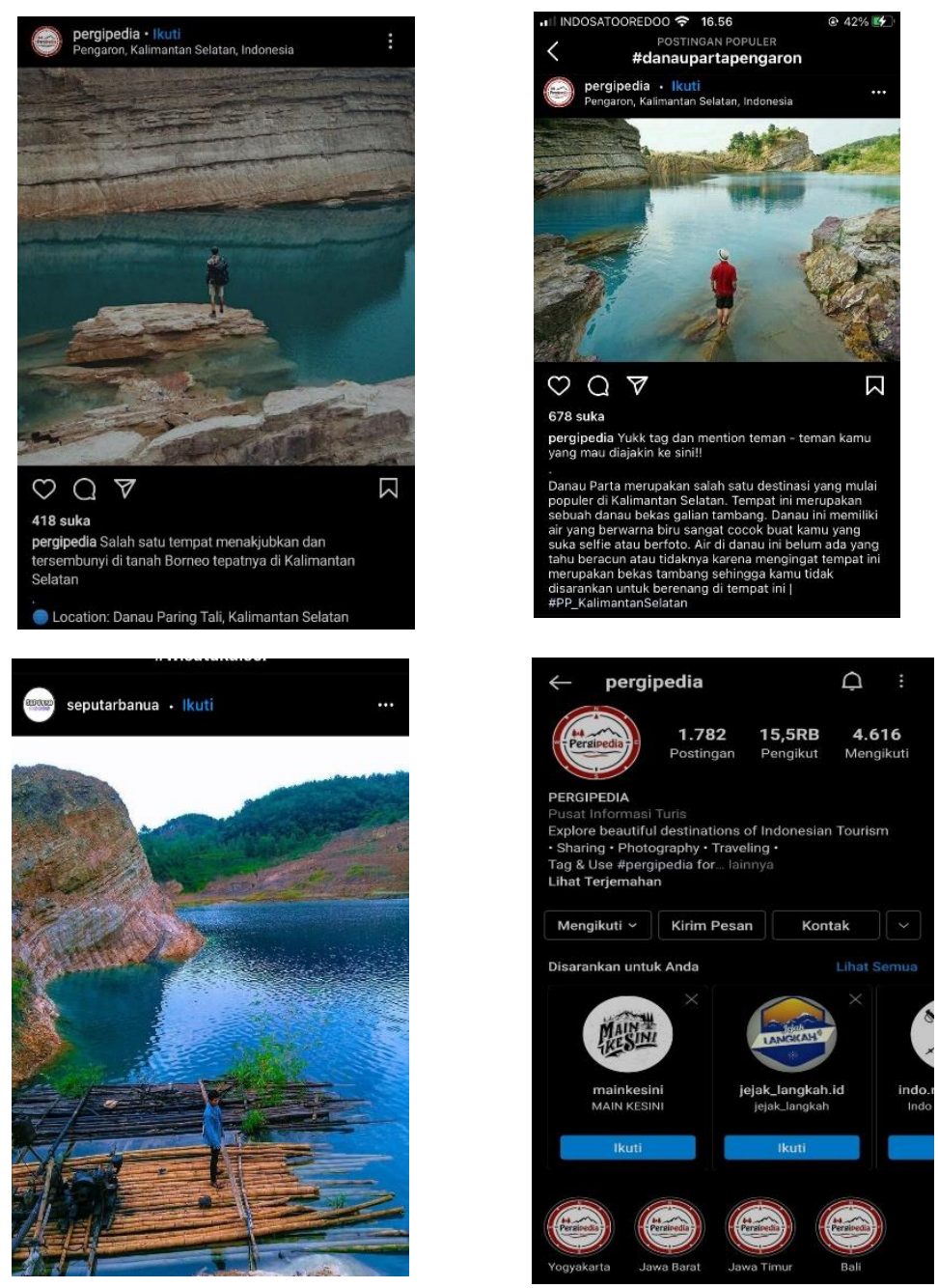

Gambar 6. Branding Danau Biru Desa Paring Tali Melalui Sosial Media Wisata 


\section{Ketercapaian Sasaran}

Setelah pelaksanaan kegiatan pengabdian yakni berupa sosialisasi dan pelatihan branding desa wisata maka berikut ini ketercapaian sasaran kegiatan:

1. Pemerintah desa memahami pentingnya pemngembangan desa wisata melalui pembentukan Kelompok Sadar Wisata (POKDARWIS).

2. Setelah dilaksanaaknnya PKM Aparatur Desa bertujuan untuk membentuk Kelompok Sadar Wisata (POKDARWIS)

3. Pemerintah Desa memahami tata cara branding desa wisata.

4. Tumbuhnya motivasi masyarakat untuk melakukan branding wisata Danau Biru Paring Tali.

5. Pemerintah Desa mengaplikasikan branding desa wisata melalui pemasangan benner dan pemasran desa wisata melalui media sosial.

\section{KESIMPULAN}

(1) Pengembangan Desa Wisata yang ada di Desa Paring Tali sempat berkembang kemudian berhenti dikarenakan status lahan yang bersinggungan dengan pihak swasta. Desa Paring Tali memalui program pengabdian masyarakat termotivasi untuk merintis kembali wisata danau biru paring tali.

(2) Desa Paring Tali memiliki potensi wisata yang bersifat lokal desa namun pengembangan sarana prasarana masih sangat terbatas.

(3) Setelah melakukan komunikasi dan koordinasi dengan pihak Swasta, Aparatur Desa, BPD, dan Masyarakat kemudian Desa Paring Tali berkeinginan membentuk Kelompok Sadar Wisata (POKDARWIS) untuk membangun kembali wisata danau biru Desa Paring Tali.

(4) Pelaksaan sosialiasi pengembangan desa wisata melalui pembentukan Kelompok Sadar Wisata (POKDARWIS) selanjutnya pengembangan wisata danau biru dikelola oleh masyarakat dan aparatur desa setempat. Setelah pelaksanaan pengabdian masyarakat, wisata danau biru selanjutnya dikelola dan dikembangkan secara langsung oleh aparatur desa dan masyarakat.

\section{UCAPAN TERIMA KASIH}

Ucapan terima kasih disampaikan kepada FISIP Universitas Lambung Mangkurat dan Pemerintah Desa yang berkenan mendukung program pengabdian masyarakat ini.

\section{REFERENSI}

Buku :

Antara, Made. dan Arida, Sukma. 2015. Panduan Pengelolaan Desa Wiata Berbasis Potensi Lokal: Denpasar.

I Made Wirartha. 2006. Pedoman Penulisan Usulan Penelitian, Skripsi dan Tesis. Yogyakarta: Andi.

Kementrian Pariwisata dan Ekonomi Kreatif. 2021. Pedoman Desa Wisata.

Prasetyo. Bambang dan Febriani, Nufian. 2020. Strategi Branding Teori dan Perspektif Komunikasi dalam Bisnis. UB Press: Malang.

Prasetyo. Bambang dan Febriani, Nufian. 2020. Strategi Branding Teori dan Perspektif Komunikasi dalam Bisnis. UB Press: Malang.

Rahim, Firmansyah. 2012. Pedoman Kelompok Sadar Wisata: Jakarta.

\section{Jurnal:}

Agung Istri Andriyani, Anak. Martono, Edi. Muhammad. Pemberdayaan Masyarakat Melalui Pengembangan Desa Wisata dan Impliksinya Terhadap Ketahanan Sosial Budaya Wilayah (Studi di Desa Wisata Penglipuran di Bali). Jurnal Ketahanan Nsional. Vol 23 No. 1. 2017: 2. 